\title{
Dry and moist heating-induced changes in protein molecular structure, protein subfraction, and nutrient profiles in soybeans
}

\author{
Samadi ${ }^{1}$ and P. Yu ${ }^{2}$ \\ College of Agricultural and Bioresources, University of Saskatchewan Saskatoon, SK, S7N 5AB, Canada
}

\begin{abstract}
Heat processing has been used to improve protein utilization and availability of animal nutrition. However, to date, few studies exist on heat-induced protein molecular structure changes on a molecular basis. The aims of this study were to use molecular spectroscopy as a novel approach to determine heat-induced protein molecular structure changes affected by moist and dry heating and quantify protein molecular structures and nutritive value in the rumen and intestine in dairy cattle. In this study, soybean was used as a model for feed protein and was autoclaved at $120^{\circ} \mathrm{C}$ for $1 \mathrm{~h}$ (moist heating) and dry heated at $120^{\circ} \mathrm{C}$ for $1 \mathrm{~h}$. The parameters assessed in this study included protein structure $\alpha$-helix and $\beta$-sheet and their ratio, protein subfractions associated with protein degradation behaviors, intestinal protein availability, and energy values. The results show that heat treatments changed the protein molecular structure. Both dry and moist heating increased the amide I-to-amide II ratio. However, for the protein $\alpha$-helix-to- $\beta$-sheet ratio, moist heating decreased but dry heating increased the ratio. Compared with dry heating, moist heating dramatically changed the chemical and nutrient profiles of soybean seed. It greatly decreased soluble crude protein, nonprotein nitrogen, and increased neutral detergent insoluble protein. Both dry and moist heating treatments did not alter digestible nutrients and energy values. Heating tended to decrease the nonprotein nitrogen fraction (soluble and rapidly degradable protein fraction) and true protein 1 fraction (fast-degradable protein fraction). Conversely, the true protein 3 fraction (slowly degradable fraction) significantly increased. The in situ rumen study showed that moist heating decreased protein rumen degradability and increased intestinal digestibility of rumen-undegradable protein. Compared with the raw soybeans, dry heating did not affect rumen
\end{abstract}

\footnotetext{
Received June 13, 2011.

Accepted August 9, 2011.

${ }^{1}$ Visiting scholar from Department of Animal Husbandry, Agricultural Faculty, Syiah Kuala University-Darussalam, Banda Aceh, Indonesia.

${ }^{2}$ Corresponding author: peiqiang.yu@usask.ca
}

degradability and intestinal digestibility. In conclusion, compared with dry heating, moist heating dramatically affected the nutrient profile, protein subfractions, rumen degradability, intestinal digestibility, and protein molecular structure (amide I-to-II ratio; $\alpha$-helix-to- $\beta$ sheet ratio). The sensitivity of soybean seed to moist heating was much higher than that to dry heating in terms of the structure and nutrient profile changes.

Key words: protein molecular structure, heat processing method, nutrient availability, intestinal digestibility

\section{INTRODUCTION}

An understanding of the molecular structure of the whole protein is often vital to understanding its digestive behavior, nutritive quality, utilization, and availability in animals (Dyson and Wright, 1993; Carey, 1996; Yu et al., 2004, 2005; Doiron et al., 2009a). In ruminants, heat processing has been used to improve the utilization and availability of nutrients (Goelema et al., 1999; Jones et al., 2000; Yu et al., 2001, 2002) and inactivate anti-nutritional factors (van der Poel et al., 1990). Studies on protein structures and the change of their inherent structures because of heat treatment in relation to nutritive value and digestive behavior of protein are relatively rare. This is partially due to the fact that no analytical techniques are available that can be applied to detect inherent molecular changes of protein structures by heating processes (Doiron et al., 2009a,b). Conventional wet chemical analyses fail to detect the molecular structure difference and fail to detect structural chemical makeup, mainly because the conventional wet chemical analyses rely heavily on the use of harsh chemicals and derivatization, which can destroy the native structure (Budevska, 2002; Yu, 2004).

The objective of this study was to reveal protein molecular structures affected by 2 methods of heat processing (dry vs. moist heating) using Fourier transform/ infrared-attenuated total reflectance (FT/IR-ATR) molecular spectroscopy and to study the sensitivity of feed tissue to heating and heat-induced nutrient profile and availability changes. The hypothesis of this study was that different heating methods result in different 
effects on molecular structure changes and are highly associated with nutrient availability.

\section{MATERIALS AND METHODS}

\section{Soybean Processing Method (Moist Heating vs. Dry Heating)}

Harvested soybeans (Glycine Max) from 2 different years (2008 and 2010) were used in this study as a modeled feed protein source. A 2-kg sample of soybeans from each year was heated by moist heating (autoclaving) and dry heating (Amsco Eagle SG-3031; Steris Corp., Mentor, $\mathrm{OH}$ ) for $1 \mathrm{~h}$ at $120^{\circ} \mathrm{C}$. The treatment was done in 1 batch and year as replication. Control samples were kept untreated. Heated samples were subsequently cooled at room temperature $\left(20-22^{\circ} \mathrm{C}\right)$ and then ground (Braun KSM 2; Braun GmbH, Kronberg, Germany). Ground samples were fitted through a 2 -mm screen.

\section{Molecular Spectroscopy}

The molecular spectral data of soybean seed was collected and corrected with the background spectrum using Jasco FT/IR-ATR 4200 (Jasco Inc., Easton, MD). The spectra were generated in transmission mode with mid-IR (ca. 4,000-800 $\mathrm{cm}^{-1}$; Figure 1) and fingerprint region (ca. 1,800-800 $\mathrm{cm}^{-1}$; Figure 2) with spectral resolution of $4 \mathrm{~cm}^{-1}$. The FT/IR spectral data of each area was collected using Ominic 7.2 (Spectra-Tech Inc., Madison, WI) software. Chemical functional groups were identified according to published reports (Kemp, 1991; Himmelsbach et al., 1998; Wetzel, et al., 1998; Miller et al., 2000; Wetzel, 2001). The regions of specific interest in this present study included the protein amide I, II, and protein structure of $\alpha$-helix and $\beta$-sheet in the IR regions of approximately 1,715 to1,480 $\mathrm{cm}^{-1}$ (Figures 3 and 4 ). The ratios of amide I and II and $\alpha$-helix and $\beta$-sheet spectral intensities were calculated (Figure 4).

\section{Animals and Diets}

To study in situ protein rumen degradation, 2 lactating Holstein cows were used in this study with flexible rumen cannulas (10-cm i.d.; Bar Diamond Inc., Parma, ID). Cows were housed in pens of approximately $1.5 \times$ $3 \mathrm{~m}$ in the research barn at the University of Saskatchewan. The diets of the cows consisted of $51 \%$ barley silage, $15 \%$ chopped alfalfa hay, and $33 \%$ concentrates (24\% DAC-525; 9\% DAC-449; formulated by David A. Christensen, University of Saskatchewan, Saskatoon, Canada) according to NRC requirements (NRC, 2001).
Water was supplied ad libitum and the cows were fed twice daily at 0800 and $1600 \mathrm{~h}$ with half the ration fed at each time. All animal care and handling used in this study was in accordance with the guideline protocols approved by the Canadian Council on Animal Care (1993).

\section{Rumen Incubation}

Ruminal degradation characteristics were determined using an in situ method. Sample treatments were incubated for $16 \mathrm{~h}$ in 2 runs by using 2 lactating cows. The method of rumen incubation followed the department standard (Yu et al., 2003a). Approximately $7 \mathrm{~g}$ of sample was placed into coded nylon bags $(10 \times 12 \mathrm{~cm})$ with a pore size of $41 \mu \mathrm{m}$ (Screentec Corp., Mississauga, ON, Canada). All samples were placed in a polyester mesh bag $(45 \times 45 \mathrm{~cm})$ with a $90-\mathrm{cm}$ length of rope to anchor it to the cannula. A plastic bottle $(250 \mathrm{~mL})$ filled with gravel was also placed in the polyester mesh bag to maintain the samples in the liquid levels of the rumen. After $16 \mathrm{~h}$ of incubation, the bags were removed from the rumen and rinsed with cold water to remove excess ruminal contents. The bags were then washed in groups of 10 with $2 \mathrm{~L}$ of cool water without detergent 5 times. The last rinse cycle of water had to be clear. Samples in washed bags were dried at $55^{\circ} \mathrm{C}$ using a forced-air oven for $48 \mathrm{~h}$ and then stored at $4^{\circ} \mathrm{C}$ until analysis. The residues were pooled according to treatment, in situ run, cows, and year and stored for chemical analysis.

\section{Chemical Analysis}

Laboratory samples of the soybean and rumen residues were prepared by grinding to pass through a 1-mm screen using a Retsch ZM 100 mill (Retsch Inc., Newtown, PA). All samples were then analyzed for DM (AOAC, 1990; method 930.15), ash (AOAC, 1990; method 942.05), ether extract (EE; AOAC, 1990; method 920.39), and CP (AOAC, 1990; method 984.13; Kjeltec 2400; Foss North America, Eden Prairie, MN) content. The ADIN and NDIN values were determined according to the procedures of Lacitra et al., (1996). The NPN content was determined by the precipitation of true protein in the filtrate with TCA (final concentration 10\%) and determined as the difference between total $\mathrm{N}$ and the $\mathrm{N}$ content of the residue after filtration (Roe et al., 1990). The starch was analyzed by using the Megazyme Total Starch Assay Kit (Megazyme International Ireland, Bray, Co. Wicklow, Ireland; AOAC, 1990; method 996.11). Acid detergent insoluble protein (ADIP) and neutral detergent insoluble protein (NDIP) were calculated as ADIP = 


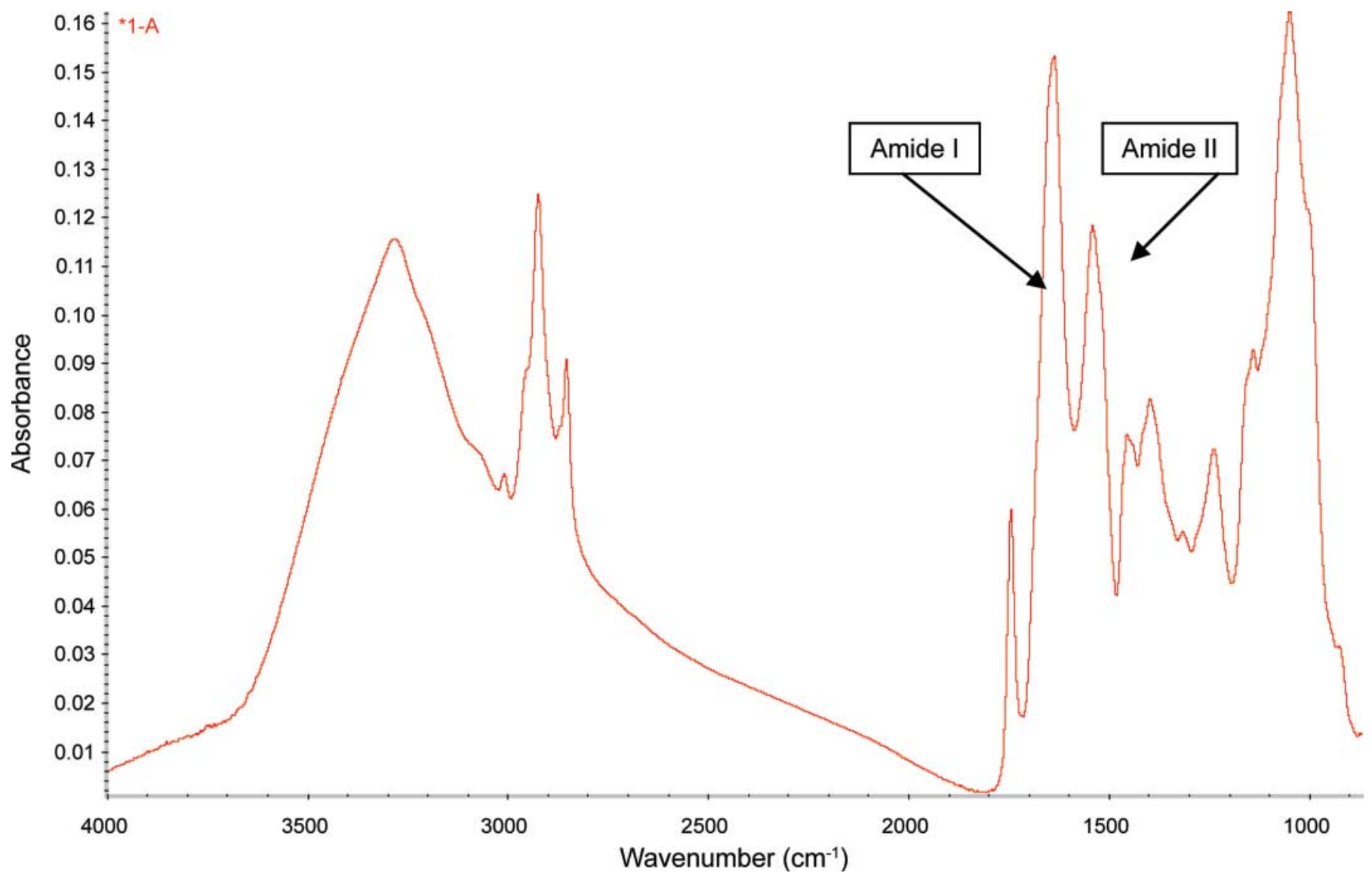

Figure 1. Typical JASCO Fourier transform/infrared-attenuated total reflectance (FT/IR-ATR; JASCO Inc., Easton, MD) molecular spectrum in soybean (raw, finely ground) in the region ca. 4,000 to $800 \mathrm{~cm}^{-1}$ showing chemical function groups of protein amide I and II. Color version available in the online PDF.

$6.25 \times \mathrm{ADIN}$ and $\mathrm{NIDP}=6.25 \times \mathrm{NDIN}$, respectively Total soluble CP was determined by incubating the sample with bicarbonate-phosphate buffer and filtering through Whatman \#54 filter paper (Roe et al., 1990). The ADF, NDF, and acid detergent lignin values were analyzed according to the procedures of Van Soest et al. (1991) by the Ankom filter bag method (Ankom A200 filter bag technique; Ankom Technology, Fairport, NY) with a modified fat extraction procedure by including a 2-h ether extract before the standard Ankom procedure. Acetone was used for the extraction protocol. This minimizes the error of measurements due to the high content of oil in the canola samples. The NDF content was determined without sodium sulfite and with the inclusion of heat-stable $\alpha$-amylase (Van Soest et al., 1991). The total carbohydrate (CHO) content was determined according to the NRC (2001): $\mathrm{CHO}=$ $100-\mathrm{EE}-\mathrm{CP}$ - ash. The NFC content was calculated according to the NRC (2001): NFC $=100-(\mathrm{NDF}-$ NDIP) - EE - CP - ash.

\section{Fractionations of Protein Fractions According to the Cornell Net Carbohydrate and Protein System}

Fractionations of $\mathrm{CP}$ were determined based on the Cornell Net Carbohydrate Protein System (CNCPS; Sniffen et al., 1992). By using this system, the characteristics of the $\mathrm{CP}$ are partitioned as follows: NPN (PA) fraction, true protein (PB) fraction, and unavailable protein (PC) fraction. Due to different rates of degradation in the rumen, fraction $\mathrm{PB}$ is further divided into 3 fractions (PB1, PB2, and PB3). Estimation of fraction PB2 is calculated from buffer-insoluble protein minus PB3. Fraction PB2 is insoluble in buffer but soluble in neutral detergent, whereas fraction PB3 is insoluble in both buffer and neutral detergent, but is soluble in acid. Fraction PC is the acid detergentinsoluble $\mathrm{N}$, which is highly resistant to breakdown by microbial and mammalian enzymes, and it is assumed to be unavailable to animals (Sniffen et al., 1992). The relative rumen degradation rates of the 5 protein frac- 


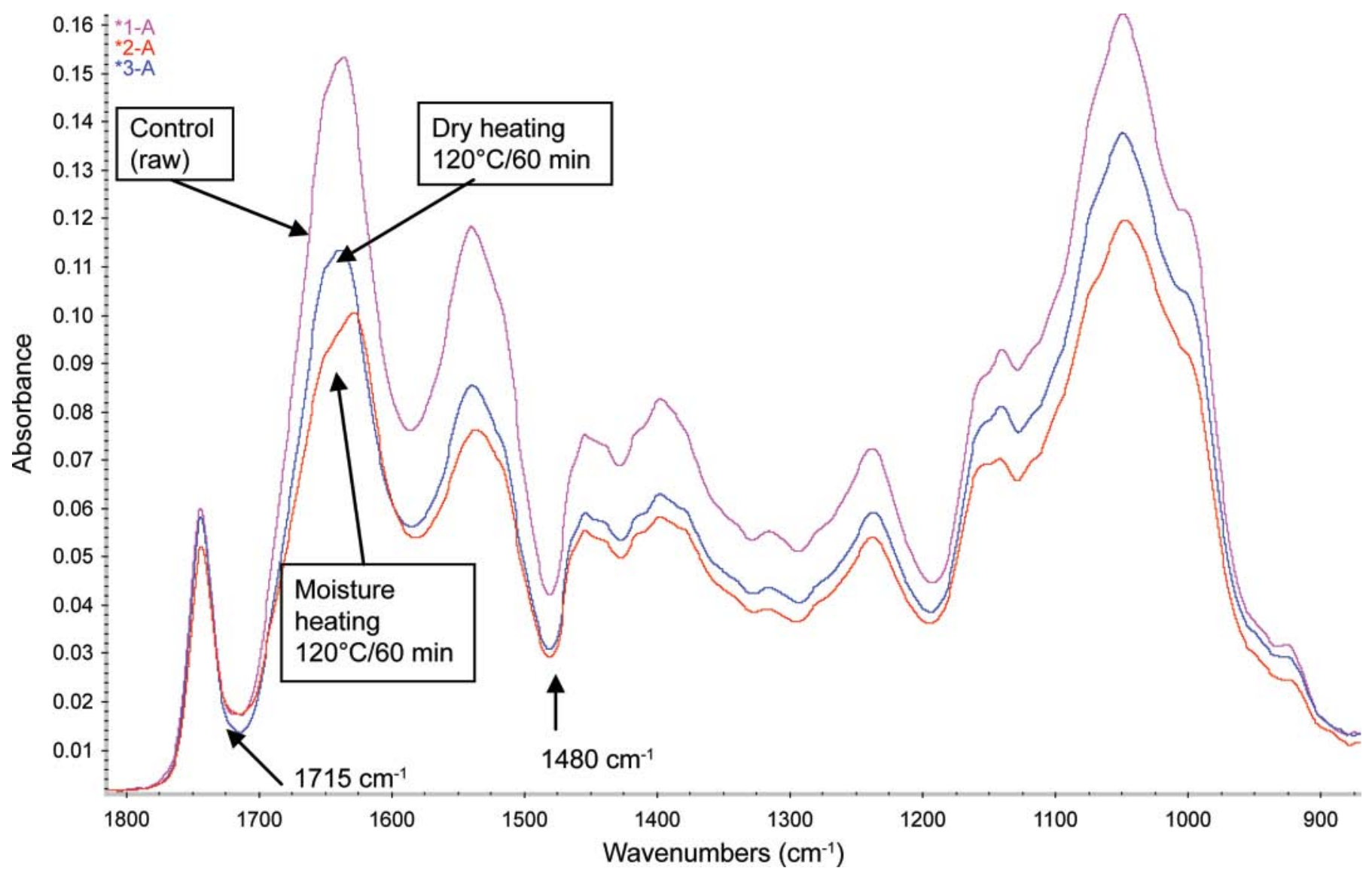

Figure 2. Protein amide I and II spectral features in typical JASCO Fourier transform/infrared-attenuated total reflectance (FT/IR-ATR; JASCO Inc., Easton, MD) molecular spectrum in raw soybean (raw, finely ground), dry-heated (oven heating at $120^{\circ} \mathrm{C}$ for 60 min), and moistheated soybean (autoclaved heating at $120^{\circ} \mathrm{C}$ for $60 \mathrm{~min}$ ) in the region ca. 1,715 to $1,480 \mathrm{~cm}^{-1}$. Color version available in the online PDF.

tions have been described by Sniffen et al. (1992) as follows: fraction PA is assumed to be infinity, fraction $\mathrm{PB} 1$ is 1.20 to $4.00 / \mathrm{h}$, fraction PB2 is 0.03 to $0.16 / \mathrm{h}$, fraction $\mathrm{PB} 3$ is 0.0006 to $0.0055 / \mathrm{h}$, and fraction $\mathrm{PC}$ is considered to be undegradable.

\section{Energy Values}

The energy values of total digestible nutrients $\left(\mathbf{T D N}_{1 \mathrm{x}}\right)$, digestible energy $\left(\mathbf{D E}_{3 \mathrm{x}}\right), \mathrm{ME}_{3 \mathrm{x}}, \mathrm{NE}_{\mathrm{L3x}}$, were estimated based on the summative approach from NRC (2001) and $\mathrm{ME}, \mathrm{NE}_{\mathrm{M}}$, and $\mathrm{NE}_{\mathrm{G}}$ were calculated using the NRC beef model (NRC, 1996).

\section{Intestinal Protein Digestion Determination}

Determination of intestinal rumen undegraded feed protein digestibility was done according to the method outlined by Calsamiglia and Stern (1995). The brief procedure is as follows: nylon bags containing feed samples were incubated for $16 \mathrm{~h}$. Residue containing approximately $15 \mathrm{mg}$ of $\mathrm{N}$ after ruminal exposure was incubated for $1 \mathrm{~h}$ in $10 \mathrm{~mL}$ of a $0.1 \mathrm{~N}$ HCL solution containing $1 \mathrm{~g}$ of pepsin/L in a $15-\mathrm{mL}$ centrifugation tube. After incubation, the $\mathrm{pH}$ was neutralized with 0.5 $\mathrm{mL}$ of $1 \mathrm{~N} \mathrm{NaOH}$ and $13.5 \mathrm{~mL}$ of pancreatin solution (0.5 $\mathrm{M} \mathrm{KH}_{2} \mathrm{PO}_{4}$ buffer standardized at $\mathrm{pH} 7.8$, containing $50 \mathrm{mg}$ of thymol $/ \mathrm{kg}$ and $3 \mathrm{~g}$ of pancreatin/L) and incubated at $38^{\circ} \mathrm{C}$ for $24 \mathrm{~h}$ in a shaker water bath. After incubation, $3 \mathrm{~mL}$ of a $100 \%$ (wt/vol) TCA solution was immediately added to precipitated undigested protein and centrifuged at $10,000 \times g$ for $15 \mathrm{~min}$ at room temperature $\left(20-22^{\circ} \mathrm{C}\right)$. The supernatant was then analyzed for soluble $\mathrm{N}$ content (Calsamiglia and Stern, 1995).

\section{Statistical Analysis}

The statistical analysis of chemical profile, protein subfraction, energy values, and FT/IR spectral analysis were performed using the MIXED procedure of SAS (SAS Institute, 1999). The model used for analysis was

$$
Y_{i j}=\mu+T_{i}+e_{i j}
$$



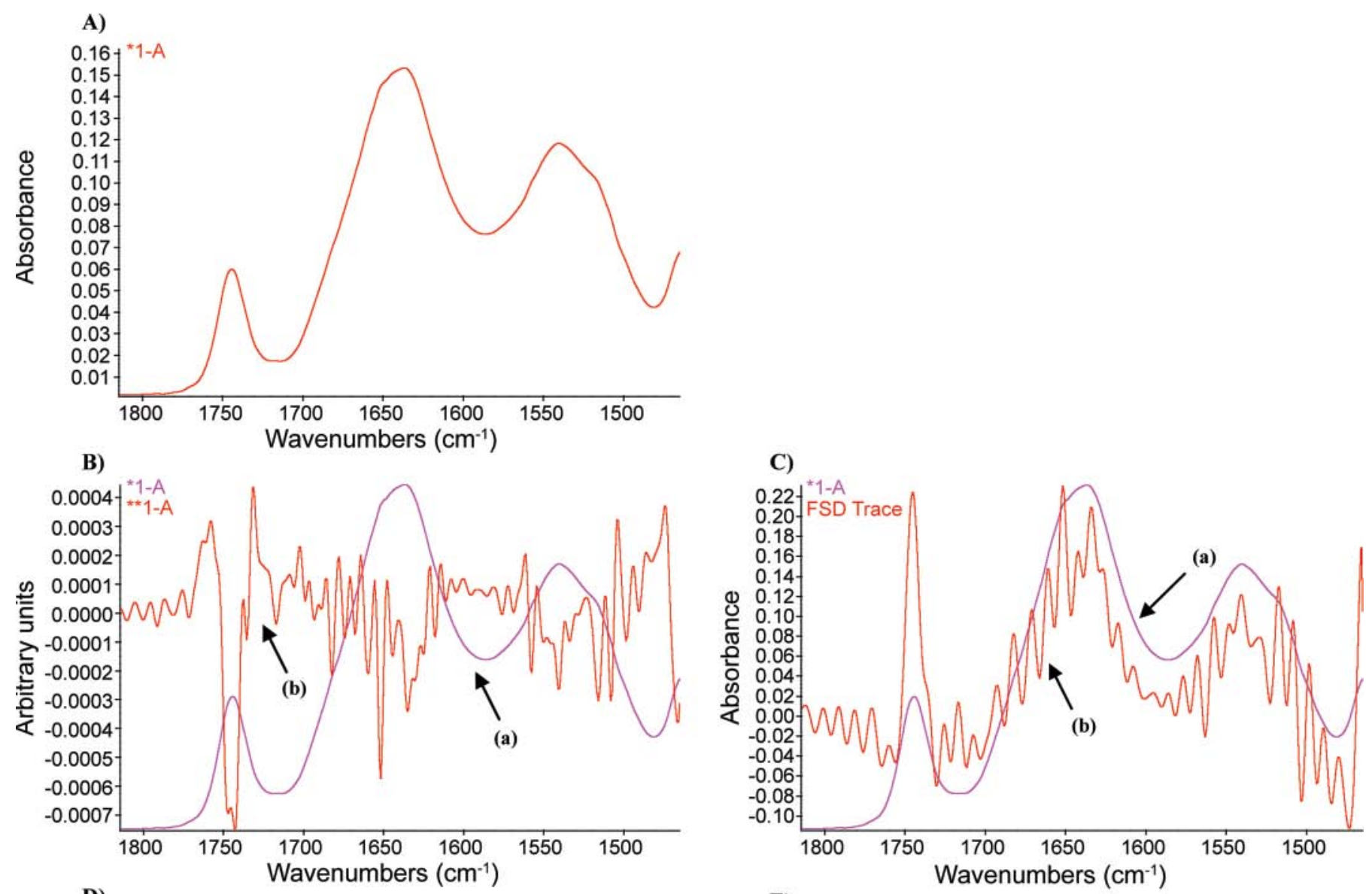

D)

E)
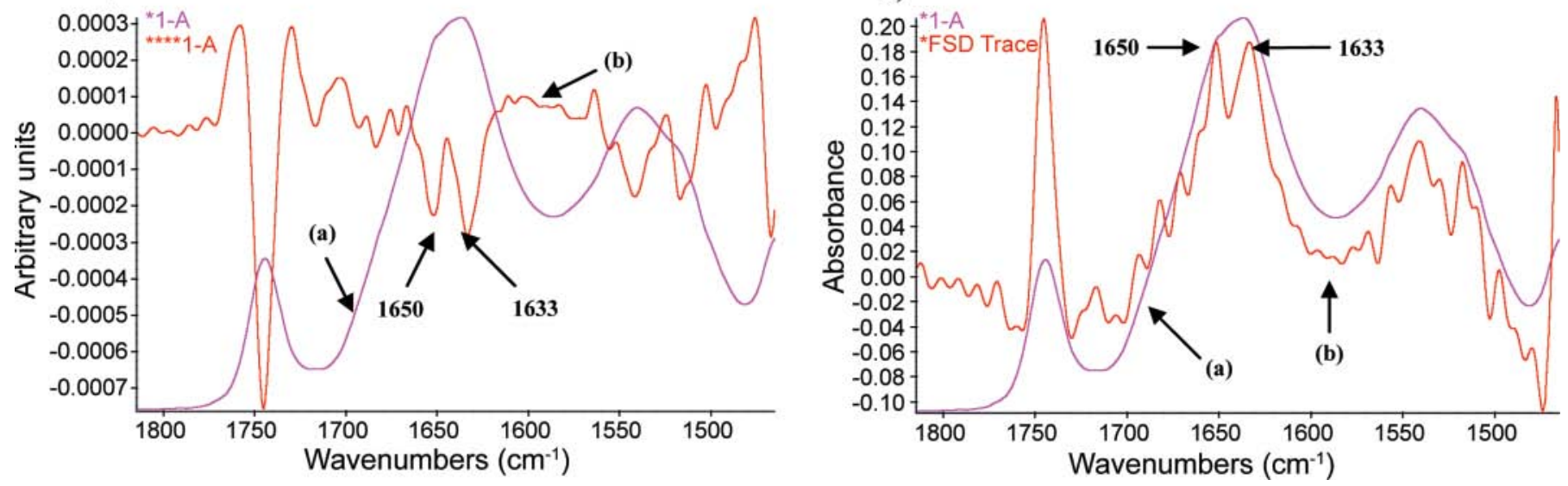

Figure 3. The JASCO Fourier transform/infrared-attenuated total reflectance (FT/IR-ATR; JASCO Inc., Easton, MD) spectrum, the second-derivative spectrum, and Fourier self-deconvolution (FSD) spectrum of soybean (raw, fine ground) showing both the second-derivative and FSD spectrums of $\alpha$-helix at ca. $1,650 \mathrm{~cm}^{-1}$ and $\beta$-sheet at ca. $1,633 \mathrm{~cm}^{-1}$. (A) Amide I and II region at ca. $1,715-1,480 \mathrm{~cm}^{-1} ;(B)$ secondderivative spectrum of the amide I and II region ( $\mathrm{a}=$ original spectrum; $\mathrm{b}=$ second-derivative spectrum showing noise peaks); (C) spectrum of amide I and II region ( $\mathrm{a}=$ original spectrum; $\mathrm{b}=$ FSD spectrum showing noise peaks; bandwidth $=4.0$; enhancement $=3.0$ ); $(\mathrm{D})$ secondderivative spectrum of the amide I and II region ( $\mathrm{a}=$ original spectrum; $\mathrm{b}=$ second-derivative spectrum after smoothing at a factor of 13 showing $\alpha$-helix at $1,650 \mathrm{~cm}^{-1}$ and $\beta$-sheet at $\left.1,633 \mathrm{~cm}^{-1}\right) ;(\mathrm{E})$ spectrum of the amide I and II region $(\mathrm{a}=$ original spectrum; $\mathrm{b}=$ spectrum after smoothing at a factor of 15$)$. Color version available in the online PDF.

where $Y_{i j}$ is an observation on the dependent variable $i j ; \mu$ is the population mean for the variable; $T_{i}$ is the effect of heat treatment (dry vs. moist heating), as a fixed effect; and $e_{i j}$ is the random error associated with the observation $i j$. The year was used as replication. When a significant difference was detected $(P<0.05)$, means were separated using the least significant difference test. 
a)

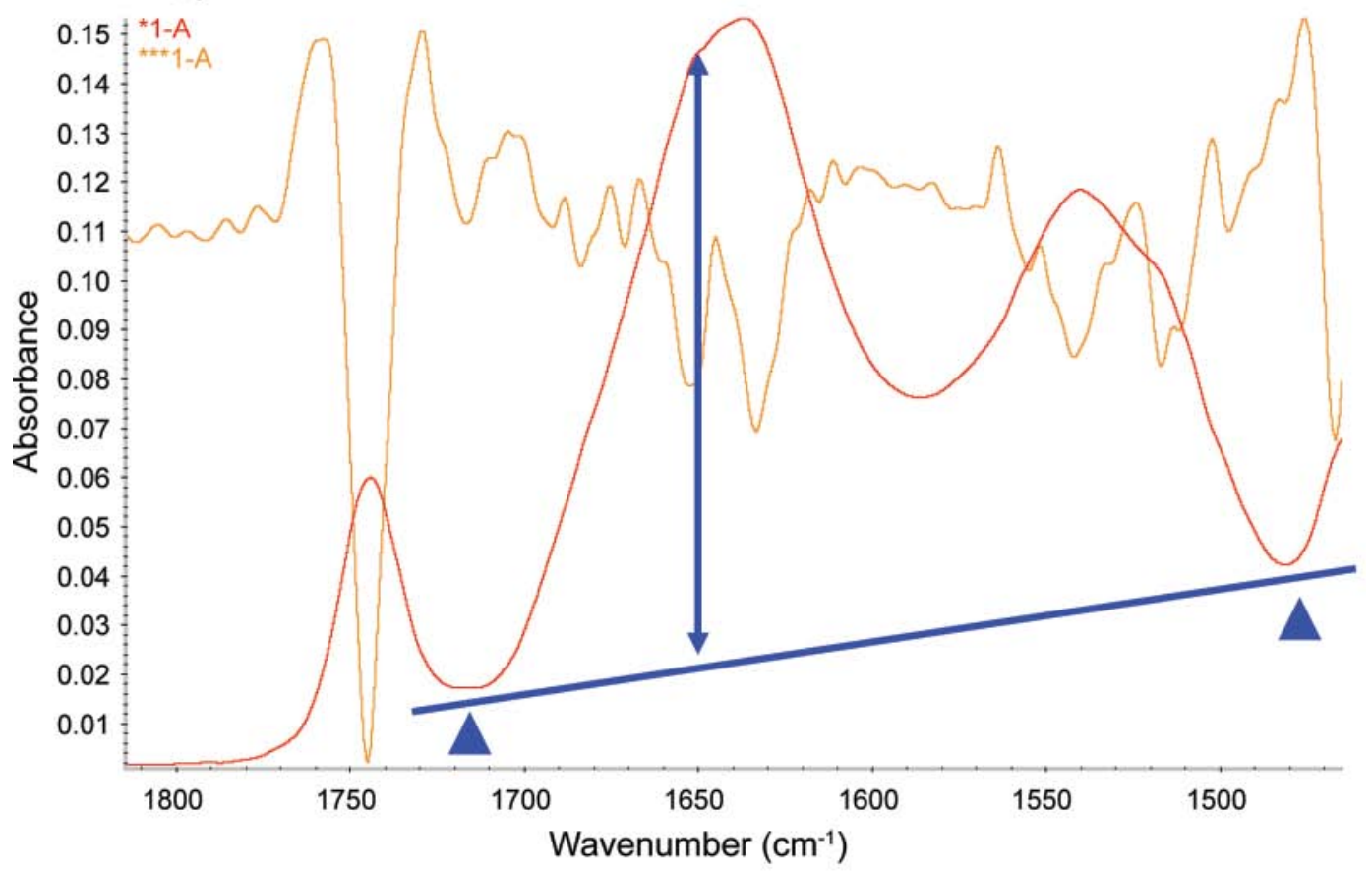

b)

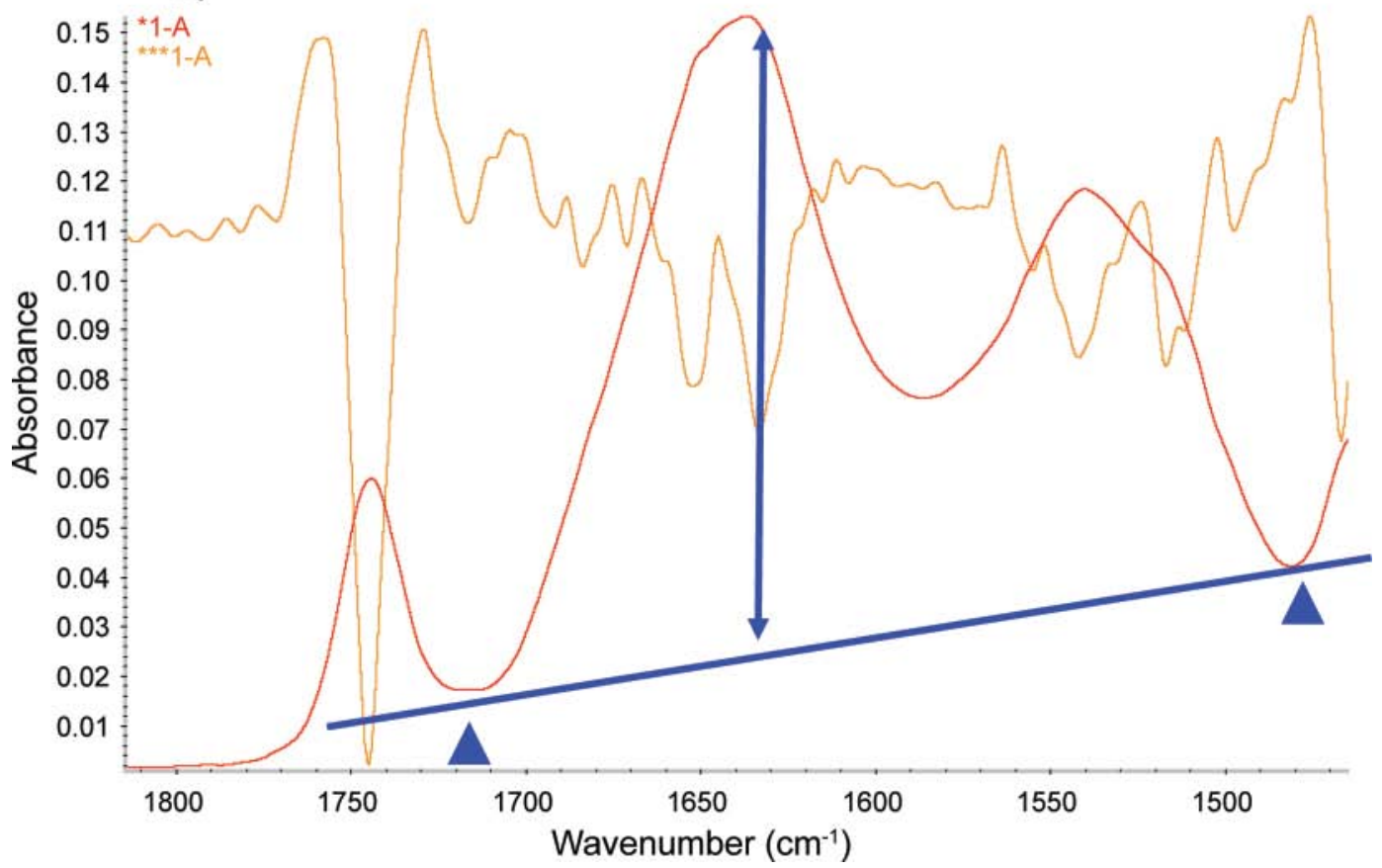

Figure 4. Typical JASCO Fourier transform/infrared-attenuated total reflectance (FT/IR-ATR; JASCO Inc., Easton, MD) spectrum of soybean (raw, finely ground): $\alpha$-helix peak center at ca. $1,650 \mathrm{~cm}^{-1}$ and $\beta$-sheet peak center at ca. 1,633 $\mathrm{cm}^{-1}$ and baseline: ca. 1,715 to 1,480 $\mathrm{cm}^{-1}$. The ratio of $\alpha$-helix to $\beta$-sheet was calculated by ratio peak height intensity ratio of ca. 1,650 to ca. $1,633 \mathrm{~cm}^{-1}$. (a) Peak height of $\alpha$-helix (peak center: ca. 1,650 $\mathrm{cm}^{-1}$; baseline: ca. 1,715-1,480 $\mathrm{cm}^{-1}$ ); (b) peak height of to $\beta$-sheet (peak center: ca. 1,633 $\mathrm{cm}^{-1}$; baseline: ca. 1,715-1,480 $\mathrm{cm}^{-1}$ ). Color version available in the online PDF.

Statistical analysis of in situ rumen degradation and digestibility were performed using the MIXED procedure of SAS (SAS Institute, 1999). The model used for analysis was

$$
Y_{i j k}=\mu+T_{j}+r_{k}+e_{i j k},
$$

where $Y_{i j k}$ is an observation on the dependent variable $i j ; \mu$ is the population mean for the variable; $T_{j}$ is the 
Table 1. The structural characteristics of protein by using Fourier transform/infrared-attenuated total reflectance (FT/IR-ATR) molecular spectroscopy: comparison of raw (control) versus heat treatments of soybean seeds

\begin{tabular}{|c|c|c|c|c|c|c|}
\hline \multirow[b]{2}{*}{ Item } & \multicolumn{3}{|c|}{ Treatment $^{1}$} & \multirow[b]{2}{*}{ SEM } & \multirow{2}{*}{$\begin{array}{c}\text { Contrast } \\
\text { Control } \\
\text { vs. HT }\end{array}$} & \multirow[b]{2}{*}{$P$-value } \\
\hline & Control & HT-1 & HT-2 & & & \\
\hline \multicolumn{7}{|c|}{ Protein amide (ca. $1,715-1,480 \mathrm{~cm}^{-1}$ ) } \\
\hline Amide I & $7.492^{\mathrm{a}}$ & $6.003^{\mathrm{b}}$ & $6.262^{\mathrm{b}}$ & 0.0915 & $<0.001$ & 0.003 \\
\hline Amide II & $4.454^{\mathrm{a}}$ & $3.441^{\mathrm{b}}$ & $3.693^{\mathrm{b}}$ & 0.0586 & $<0.001$ & 0.002 \\
\hline Ratio amide I:amide II & $1.686^{\mathrm{a}}$ & $1.744^{\mathrm{b}}$ & $1.699^{\mathrm{b}}$ & 0.0040 & 0.030 & 0.008 \\
\hline$\beta$-sheet (height) & $0.103^{\mathrm{a}}$ & $0.079^{\mathrm{b}}$ & $0.085^{\mathrm{b}}$ & 0.0013 & $<0.001$ & 0.001 \\
\hline Ratio $\alpha$-helix: $\beta$-sheet & $0.956^{\mathrm{a}}$ & $0.893^{\mathrm{b}}$ & $0.977^{\mathrm{a}}$ & 0.0039 & 0.127 & $<0.001$ \\
\hline
\end{tabular}

${ }^{\mathrm{a}-\mathrm{c}}$ Means within a row with different superscript letters differ $(P<0.05)$. Mean separation was done by using the least significant difference test. ${ }^{1} \mathrm{HT}=$ heat treatment; HT- $1=$ autoclaved at $120^{\circ} \mathrm{C}$ for $1 \mathrm{~h}$; HT- $2=$ dry heating at $120^{\circ} \mathrm{C}$ for $1 \mathrm{~h}$.

effect of heat treatment (dry vs. moist heating), as a fixed effect; $r_{k}$ is the effect of cow, as a random effect; and $e_{i j k}$ is the random error associated with the observation $i j$. The year is used as replication. When a significant difference was detected $(P<0.05)$, means were separated using the Tukey test.

\section{RESULTS AND DISCUSSION}

\section{Heat-Induced Characteristics of Protein Molecular Structure Changes}

The inherent protein structures influence the protein access to gastrointestinal digestive enzymes. Different $\alpha$-helix-to- $\beta$-sheet ratio profiles affected the feed protein access to intestinal digestive enzymes (Doiron et al., 2009a). Even if tissues contain the same protein content, their nutritive value may be different if their $\alpha$-helixto- $\beta$-sheet ratios in their protein secondary structures are different. Characteristics of protein secondary structure of soybean seeds between heating treatments are presented in Table 1. The results from our study show that moist heating decreased significantly $(P<$ $0.05)$ the ratio of $\alpha$-helix to $\beta$-sheet, but increased the amide I-to-II ratio. Again, dry heating did not affect $(P<0.05)$ the ratio of $\alpha$-helix to $\beta$-sheet and amide I to II. The results were related to the degradability in situ data. The moist heat treatment altered in situ rumen degradation of DM and $\mathrm{CP}$, and also changed intestinal digestibility of RUP. The change of the ratio of $\alpha$-helix to $\beta$-sheet by moist heating was also reported by Doiron et al. (2009a). The alteration in the protein structure ratio was probably caused by denaturation of $\alpha$-helix and $\beta$-sheet during the heating process. The experiment conducted by $\mathrm{Yu}$ et al. (2005) found that dry heating decreased the percentage of $\alpha$-helix (from 47.1 to $36.1 \%$ ), increased the percentage of $\beta$-sheet (from 37.2 to $49.8 \%$ ), and decreased the $\alpha$-helix-to- $\beta$ - sheet ratio (1.3 to 0.7 ) of the golden flaxseed tissues. The heat-induced structural changes affected nutrient availability in the rumen and intestine.

\section{Heat-Induced Chemical and Nutrient Profile Changes}

The chemical profile changes induced by the heat treatments (moist vs. dry heating) are shown in Table 2. Dry matter of soybean seeds increased $(P<0.05)$ from $90.3 \%$ (control) to $93.5 \%$ (dry heating). The value of EE in our study was significantly influenced $(P<$ $0.05)$ by the heat treatments. Studies conducted by Oomah and Kenaschuk (1995) and Doiron et al. (2009a) also indicated that heat treatment increased the EE extractability of the samples. Doiron et al. (2009a) indicated that the increase of $\mathrm{EE}$ due to heat treatments (both moist and dry heating) was caused by physical change such as denaturation, which would remove the effect of steric hindrance, exposing the inside of the oil bodies to one another, allowing them to coalesce, or through changes to the charged surfaces of the protein responsible for the structure of the oil protein matrix (Huang, 1992).

Total carbohydrate in our study was not significantly influenced by the heat treatments, although a numerical decrease in the values of total carbohydrate by the heat treatments occurred (Table 2). This result was different from those of Doiron et al. (2009a) who reported that heat treatment decreased the carbohydrate concentration. The decrease in carbohydrate concentration was probably caused by the increase of $\mathrm{EE}$ content after heat treatment (Doiron et al., 2009a). In our study, NDF concentration was significantly increased $(P<$ 0.05 ) by moist heating ( 18.3 vs. $28.7 \%$ of DM). This result was in accordance with previous studies (Mustafa et al., 2003a; Gonthier et al., 2004; Doiron et al., 2009a). However, dry heating did not change the NDF content compared with the raw sample. 
Table 2. Chemical profiles: comparison of raw (control) versus dry and moist heat treatments of soybean seeds

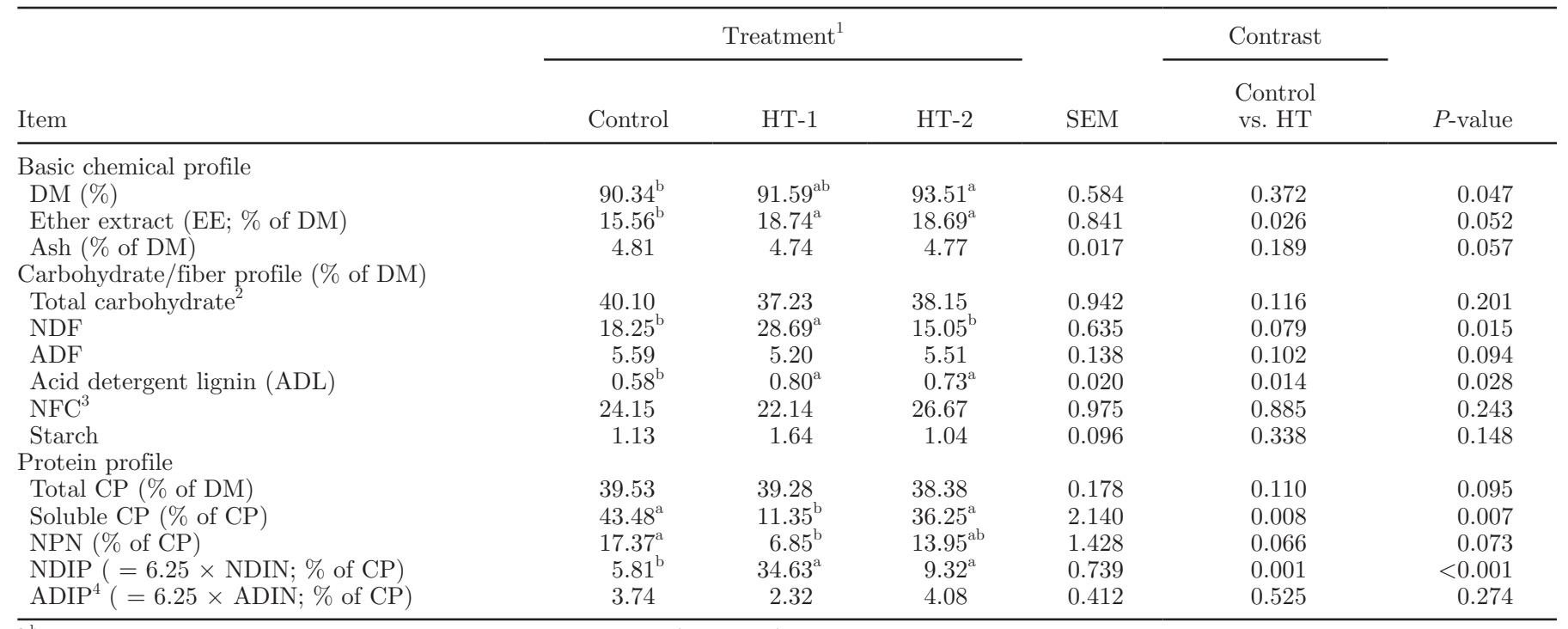

${ }_{\mathrm{a}, \mathrm{b}}$ Means within a row with different superscript letters differ $(P<0.05)$. Mean separation was done by using the least significant difference test. ${ }^{1} \mathrm{HT}=$ heat treatment; HT- $1=$ autoclaved at $120^{\circ} \mathrm{C}$ for $1 \mathrm{~h}$; HT-2 = dry heating at $120^{\circ} \mathrm{C}$ for $1 \mathrm{~h}$.

${ }^{2}$ Total carbohydrate was calculated as follows: carbohydrate $=100-\mathrm{EE}-\mathrm{CP}-$ ash (NRC, 2001).

${ }^{3} \mathrm{NFC}=100-[\mathrm{NDF}-$ neutral detergent-insoluble protein (NDIP) $]-\mathrm{EE}-\mathrm{CP}-\operatorname{ash}(\mathrm{NRC}, 2001)$.

${ }^{4} \mathrm{ADIP}=$ acid detergent-insoluble protein.

Both heating methods significantly increased the acid detergent lignin content $(P<0.05)$. No differences were detected in NFC and starch contents, which were similar to those in the study by Doiron et al. (2009a).

Total CP was not affected by the method of heat treatment. This result was similar to those in previous studies (Gonthier et al., 2004; Doiron et al., 2009a).
Soluble CP significantly decreased $(P<0.05)$ from $43.5 \%$ in the control to $11.4 \%$ in moist heating. This result was supported by a previous study of moisture in Vimy flaxseed (Doiron et al., 2009a). In our study, moist heating significantly $(P<0.05)$ decreased NPN concentration. This result is in line with the results reported by Mustafa et al. (2003b) in which the NPN

Table 3. Protein subfraction profiles using the Cornell Net Carbohydrate and Protein System (CNCPS): comparison of raw (control) versus heat treatment of soybean seeds

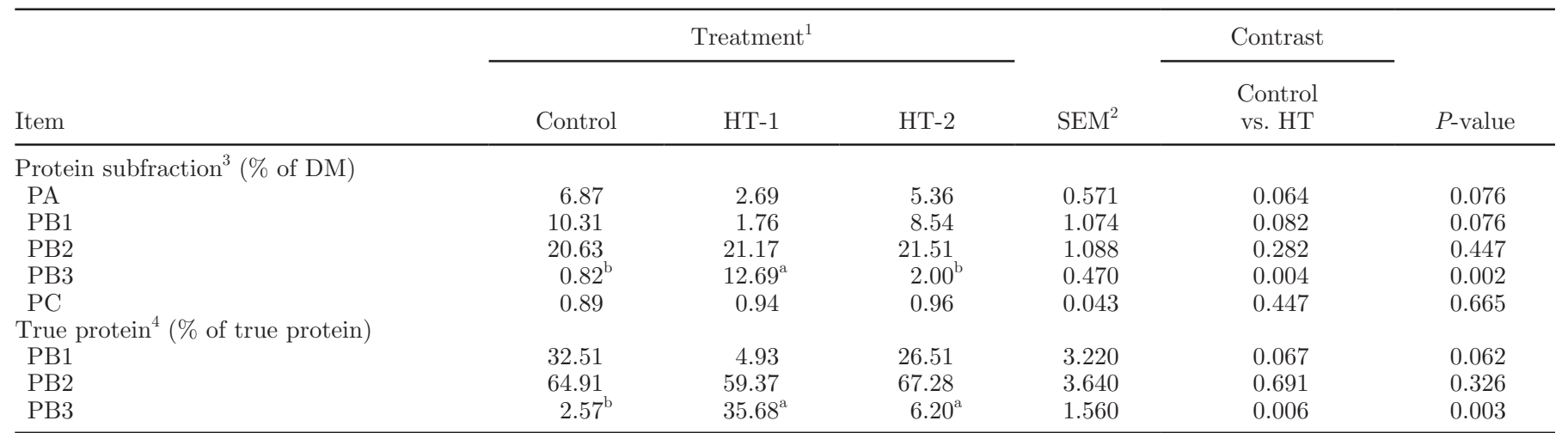

${ }^{\mathrm{a}, \mathrm{b}}$ Means within a row with different superscript letters differ $(P<0.05)$. Mean separation was done by using the least significant difference test. ${ }^{1} \mathrm{HT}=$ heat treatment; HT- $1=$ autoclaved at $120^{\circ} \mathrm{C}$ for $1 \mathrm{~h}$; HT-2 = dry heating at $120^{\circ} \mathrm{C}$ for $1 \mathrm{~h}$.

${ }^{2} \mathrm{SEM}=$ pooled standard error of the means.

${ }^{3} \mathrm{PA}=$ fraction of $\mathrm{CP}$ that is instantaneously solubilized at time zero; PB1 = fraction of $\mathrm{CP}$ that is soluble in borate-phosphate buffer and precipitated with trichloroacetic acid; PB2 = calculated as total CP minus sum of fractions PA, PB1, PB3, and PC; PB3 = calculated as the difference between the portions of total $\mathrm{CP}$ covered with $\mathrm{NDF}$ and $\mathrm{ADF}$; $\mathrm{PC}=$ fraction of $\mathrm{CP}$ recovered with $\mathrm{ADF}$ and is considered to be undegradable. It contained protein associated with lignin and tannins and heat-damaged protein such as the Maillard reaction products.

${ }^{4}$ True protein $=\mathrm{PB} 1(\%$ of $\mathrm{CP})+\mathrm{PB} 2(\%$ of $\mathrm{CP})+\mathrm{PB} 3(\%$ of $\mathrm{CP})$. 
Table 4. Digestible nutrients and estimated energy values: comparison of raw (control) versus heat treatment of soybean seeds

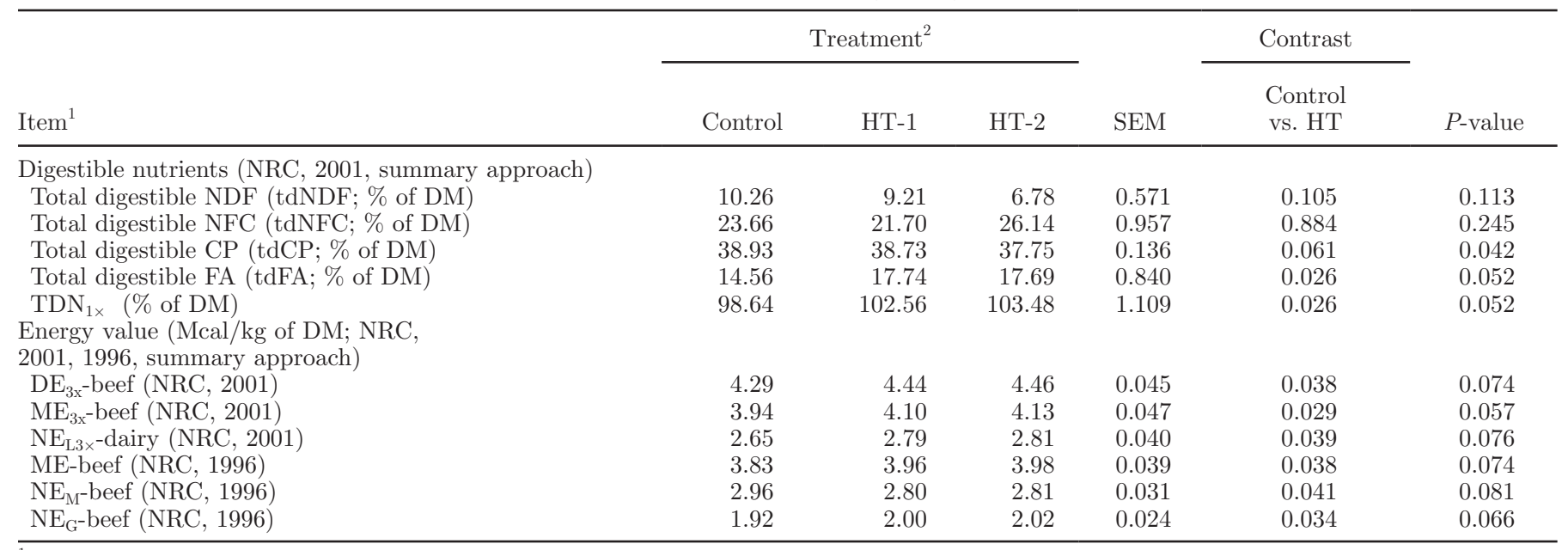

${ }^{1} \mathrm{TDN}=$ total digestible nutrients; $\mathrm{DE}=$ digestible energy.

${ }^{2} \mathrm{HT}=$ heat treatment; HT- $1=$ autoclaved at $120^{\circ} \mathrm{C}$ for $1 \mathrm{~h}$; HT- $2=$ dry heating at $120^{\circ} \mathrm{C}$ for $1 \mathrm{~h}$.

content of flaxseed decreased using a moist heat treatment. Both heating methods did not affect ADIP, but a marked increase in NDIP content from $5.8 \%$ (control) to $34.6 \%$ (moist heating method) occurred. This result was similar to those from studies conducted by Gonthier et al. (2004) for micronized flaxseed, Mustafa et al., (2003a) for moist-heated sunflower, and Doiron et al. (2009a) for Vimy flaxseed.

The above results indicated that the sensitivity of soybean tissue to heating were different between the moist and dry heating. Moist heating had a much greater effect on chemical and nutrient profiles than did dry heating.

\section{Heat-Induced Protein Subfraction Profile Changes}

Protein subfraction profiles can be changed when protein is treated physically, chemically, and biologically, such as heat treatment. Protein subfraction profiles using the Cornell Net Carbohydrate Protein System are presented in Table 3. The protein PA and PB1 fractions are degraded quickly in the rumen. The results from this study showed that NPN (PA fraction) and PB1 tended to be decreased by the moist heating from $6.8 \%$ (control) to $2.7 \%$ (moist heating) in the PA fraction, and from $10.3 \%$ (control) to $1.8 \%$ (moist heating) in the PB1 fraction. Studies conducted by Doiron et al. (2009a) had similar results to those in our study. The PB3 fraction is believed to be more slowly degraded in the rumen and that a large portion will escape from the rumen. A marked increase $(P<0.05)$ of the PB3 fraction was observed after moist heating from $0.8 \%$ (control) to $12.7 \%$ (moist heating). Doiron et al. (2009a) also reported that a significant increased of the PB3 fraction from $3.3 \%$ for the raw flaxseed to $4.9 \%$ for 1 -h moist heating. Fraction PC consists of protein bound to lignin, tannins, and Maillard reaction protein and was considered not degradable in the rumen and not available to animals (Sniffen et al., 1992). Our data showed that heat treatments did not significantly influence the PC fraction of soybean seeds. An experiment conducted by Doiron et al. (2009a) showed that the PC fraction was not affected for 20 and 40 min of heating but at 60 min of heating the PC fraction increased significantly. In summary, the methods of heating (autoclaving vs. dry heating) affected the protein subfractions, but the difference in protein subfraction change depended on the heating method (Table 3). Again, the moist heating (autoclaving) showed a more powerful penetration effect in the tissue than dry heating (roasting), which caused protein subfraction profile changes.

\section{Heat-Induced Energy Content Changes}

The prediction of digestible nutrients of the feed was based on Weiss' equations (Weiss, 1993) and prediction energy values of feed samples were according to NRC (1996; 2001). The results from our study showed that the heat treatments did not affect significantly the TDN of NDF, NFC, CP, and FA. This was in accordance with our protein fraction data, that the value of the PC fraction was not influenced by the method of heat treatment. The TDN of soybean seeds was not altered by either heating process. Heating also did not alter the energy value (ME, NE) of sample feeds, as indicated by no significant differences between the energy values of the control, moist-heated, and dry-heated soybean seeds (Table 4). The energy contents of soybean 
Table 5. In situ rumen degradation and intestinal digestibility: comparison of raw (control) versus heat treatments of soybean seeds

\begin{tabular}{|c|c|c|c|c|c|c|}
\hline \multirow[b]{2}{*}{ Item } & \multicolumn{3}{|c|}{ Treatment $^{1}$} & \multirow[b]{2}{*}{ SEM } & \multirow{2}{*}{$\begin{array}{c}\text { Contrast } \\
\text { Control } \\
\text { vs. HT }\end{array}$} & \multirow[b]{2}{*}{$P$-value } \\
\hline & Control & HT-1 & HT-2 & & & \\
\hline \multicolumn{7}{|l|}{ Rumen degradability } \\
\hline In situ rumen degradability of DM (\%) & $84.21^{\mathrm{a}}$ & $61.17^{\mathrm{b}}$ & $83.77^{\mathrm{a}}$ & 0.698 & 0.009 & 0.005 \\
\hline In situ rumen degradability of $\mathrm{CP}(\%)$ & $86.21^{\mathrm{a}}$ & $66.35^{\mathrm{b}}$ & $85.92^{\mathrm{a}}$ & 0.538 & 0.002 & $<0.001$ \\
\hline Intestinal digestibility of RUP (\%) & $82.39^{\mathrm{b}}$ & $89.79^{\mathrm{a}}$ & $79.95^{\mathrm{b}}$ & 0.766 & 0.134 & 0.025 \\
\hline
\end{tabular}

${ }_{\mathrm{a}, \mathrm{b}}$ Means within a row with different superscript letters differ $(P<0.05)$. Mean separation was done by using the least significant difference test. ${ }^{1} \mathrm{HT}=$ heat treatment; HT- $1=$ autoclaved at $120^{\circ} \mathrm{C}$ for $1 \mathrm{~h}$; HT-2 = dry heating at $120^{\circ} \mathrm{C}$ for $1 \mathrm{~h}$.

seeds (control) were about $4.29 \mathrm{Mcal} / \mathrm{kg}$ of $\mathrm{DM}\left(\mathrm{DE}_{3 \mathrm{x}}\right)$, $3.94 \mathrm{Mcal} / \mathrm{kg}$ of DM $\left(\mathrm{ME}_{3 \mathrm{x}}\right)$, and $2.65 \mathrm{Mcal} / \mathrm{kg}$ of DM $\left(\mathrm{NE}_{\mathrm{L} 3 \mathrm{x}}\right)$, which are much higher than in cereal grain. For example, Harrington barley was $3.29 \mathrm{Mcal} / \mathrm{kg}$ of $\mathrm{DM}, 2.88 \mathrm{Mcal} / \mathrm{kg}$ of DM, and $1.83 \mathrm{Mcal} / \mathrm{kg}$ of DM for $\mathrm{DE}_{3 \mathrm{x}}, \mathrm{ME}_{3 \mathrm{x}}$, and $\mathrm{NE}_{\mathrm{L} 3 \mathrm{x}}$, respectively, conducted by $\mathrm{Yu}$ et al. (2003b).

\section{Heat-Induced Rumen Protein Degradability and Intestinal Digestibility}

In situ rumen degradation of soybean DM was significantly decreased $(P<0.05)$ by moist heating from 84.2 to $61.2 \%$ for the control and moisture treatments, respectively. But no significant difference was observed between the control and dry heating (Table 5). This result was in line with studies by Mustafa et al. (2003a) and Doiron et al. (2009a). Rumen protein degradability of soybean seeds was significantly decreased $(P<0.05)$ by moist heating. Our results were in accordance with previous studies (Mustafa et al., 2003a; Sarrazin et al., 2003; Doiron et al., 2009a); however, dry heating did not affect the rumen protein degradability.

Intestinal digestibility estimation using a protocol by Calsamiglia and Stern (1995) indicated that moist heating significantly increased intestinal digestibility of RUP from 82.4 to $89.8 \%$ for the control and moisture treatment, respectively.

The increase in the PB3 fraction after moist heating probably contributed to the high value of intestinal digestibility of RUP. However, the study conducted by Doiron et al. (2009a) showed that intestinal digestibility of flaxseed protein was not significantly different between the treatments. In our study, dry heating did not affect the intestinal digestibility of RUP of soybean seeds. Heating above the optimal temperature may overprotect the protein, as stated by Stern et al. (1985), so that the protein is neither fermented in the rumen nor digested in the small intestine. In this study, none of the heat processing methods showed an overheating effect. Dry heating showed that soybean tissue was underheated, because there was not much effect.

\section{CONCLUSIONS}

In conclusion, compared with dry heating, moist heating dramatically affected the nutrient profile, protein subfraction, rumen degradability, intestinal digestibility, and protein molecular structure (amide Ito-II ratio; $\alpha$-helix-to- $\beta$-sheet ratio). The sensitivity of soybean seeds to moist heating was much higher than the sensitivity to dry heating in terms of the structure and nutrient profile changes.

\section{ACKNOWLEDGMENTS}

The present study was supported by grants from the Natural Sciences and Engineering Research Council of Canada (NSERC-Individual Discovery Grant, Canadian federal government), the Ministry of Agriculture Strategic Research Chair Program, and the Saskatchewan Agricultural Development Fund (ADF). The authors thank the Directorate General of Indonesia's Higher Education (Dikti) for financial support for travel and living under the Program of Academic Recharging (PAR) to Samadi. The authors acknowledge Zhiyuan Niu for assistance and chemical analysis and Arjan Jonker and Daalkhaijav Damiran for valuable discussion and data calculation at the Department of Animal Science, University of Saskatchewan, Canada.

\section{REFERENCES}

AOAC. 1990. Officials Methods of Analysis. 15th ed. Association of Official Analytic Chemists, Arlington, VA.

Budevska, B. O. 2002. Applications of vibrational spectroscopy in life, pharmaceutical and natural Sciences. Pages 3720-3732 in Handbook of Vibrational Spectroscopy. Vol. 5. Chalmers, J. M., Griffiths, P. M., ed. John Wiley and Sons Inc., New York, NY.

Calsamiglia, S., and M. D. Stern. 1995. A three-step in vitro procedure for estimating intestinal digestion of protein in ruminants. J. Anim. Sci. 73:1459-1465.

Canadian Council on Animal Care. 1993. Guide to the Care and Use of Experimental Animals. Vol. 1. 2nd ed. Canadian Council on Animal Care, Ottawa, ON, Canada.

Carey, F. A. 1996. Organic Chemistry. 3rd ed. McGraw-Hill, New York, NY.

Doiron, K., P. Yu, J. J. McKinnon, and D. A. Christensen. 2009a. Heat-induced protein structure and subfractions in relation to pro- 
tein degradation kinetics and intestinal availability in dairy cattle. J. Dairy Sci. 92:3319-3330.

Doiron, K. J., P. Yu, C. R. Christensen, D. A. Christensen, and J. J. McKinnon. 2009b. Detecting molecular changes in Vimy flaxseed protein structure using synchrotron FTIRM and DRIFT spectroscopic techniques: Structural and biochemical characterization. Spectroscopy 23:307-322.

Dyson, H. J., and P. E. Wright. 1993. Peptide conformation and protein folding. Curr. Opin. Struct. Biol. 3:60-65.

Goelema, J. O., A. Smits, L. M. Vaessen, and A. Wemmers. 1999. Effects of pressure toasting, expander treatment and pelleting on in vitro and in situ parameters of protein and starch in a mixture of broken peas, lupins and faba beans. Anim. Feed Sci. Technol. 78:109-126.

Gonthier, C., A. F. Mustafa, R. Berthiaume, and H. V. Petit. 2004. Effects of feeding micronized and extruded flaxseed on ruminal fermentation and nutrient utilization by dairy cows. J. Dairy Sci. $87: 1854-1863$.

Himmelsbach, D. S., S. Khalili, and D. E. Akin. 1998. FT-IR microspectroscopic imaging of flax (Linum usitatissimum L.) stems. Cell. Mol. Biol. 44:99-108.

Huang, A. H. C. 1992. Oil bodies and oleosins in seeds. Annu. Rev. Plant Physiol. Plant Mol. Biol. 43:177-200.

Jones, R. A., A. F. Mustafa, D. A. Christensen, and J. J. McKinnon. 2000. Effects of untreated and heat-treated canola presscake on milk yield and composition of dairy cows. Anim. Feed Sci. Technol. 89:97-111.

Kemp, W. 1991. Organic Spectroscopy. 3rd ed. W. H. Freeman \& Co., New York, NY.

Lacitra, G., T. M. Hernandez, and V. J. Van Soest. 1996. Standardization of procedures for nitrogen fractionation of ruminant feeds. Anim. Feed Sci. Technol. 57:347-358.

Miller, L. M., G. L. Carr, M. Jackson, P. Dumas, and G. P. Williams, 2000. The impact of infrared synchrotron radiation in biology: Past, present, and future. Synchrotron Radiation News. 13:31-38.

Mustafa, A. F., Y. P. Chouinard, D. R. Ouellet, and H. Soita. 2003a Effects of moist heat treatment on ruminal nutrient degradability of sunflower seed. J. Sci. Food Agric. 83:1059-1064.

Mustafa, A. F., C. Gonthier, and D. R. Ouellet. 2003b. Effects of extrusion of flaxseed on ruminal and postruminal nutrient digestibilities. Arch. Tierernahr. 57:455-463.

NRC. 1996. Nutrient Requirements of Beef Cattle. 7th ed. National Research Council, National Academies Press, Washington, DC.

NRC. 2001. Nutrient Requirements of Dairy Cattle. 7th rev. ed. National Research Council, National Academies Press, Washington, DC.

Oomah, B. D., and E. O. Kenaschuk. 1995. Cultivars and agronomic aspects. Pages $43-55$ in Flaxseed in Human Nutrition. S. Cunnane and L. U. Thompson, ed. AOCS Press, Champaign, IL.

Roe, M. B., C. J. Sniffen, and L. E. Chase. 1990. Techniques for measuring protein fractions in feedstuffs. Pages 81-85 in Proc. Cornell Nutrition Conf., Ithaca, NY. Cornell University, Ithaca, NY.

Sarrazin, P., A. F. Mustafa, P. Y. Chouinard, G. S. V. Raghavan, and S. A. Sotocinal. 2003. Effects of roasting on ruminal nutrient degradability of sunflower seed. J. Sci. Food Agric. 83:1219-1224.

SAS Institute. 1999. User's Guide: Statistics. 8th ed. SAS Inst. Inc., Cary, NC.
Sniffen, C. J., J. D. O'Connor, P. J. Van Soest, D. G. Fox, and J. Russell. 1992. A net carbohydrate and protein system for evaluating cattle diets: II. Carbohydrate and protein system availability. J. Anim. Sci. 70:3562-3577.

Stern, M. D., K. A. Santos, and L. D. Satter. 1985. Protein degradation in rumen and amino acids absorption in the small intestine of lactating dairy cattle fed heat-treated whole soybeans. J. Dairy Sci. $68: 45-56$.

van der Poel, A. F. B., J. Blonk, D. J. van Zuilichem, and M. G. van Oort. 1990. Thermal inactivation of lectins and trypsin inhibitor activity during steam processing of dry beans (Phaseolus vulgaris) and effects on protein quality. J. Sci. Food Agric. 53:215-228.

Van Soest, P. J., J. B. Robertson, and B. A. Lewis. 1991. Methods for dietary fiber, neutral detergent fiber, and nonstarch polysaccharides in relation to animal nutrition. J. Dairy Sci. 74:3583-3597.

Weiss, W. P. 1993. Predicting energy values of feeds. J. Dairy Sci $76: 1802-1811$

Wetzel, D. L. 2001. When molecular causes of wheat quality are known, molecular methods will supercede traditional methods. Pages 183-201 in Proceedings of the Second International Wheat Quality Conference, Manhattan, KS.

Wetzel, D. L., A. J. Eilert, L. N. Pietrzak, S. S. Miller, and J. A. Sweat. 1998. Ultraspatially-resolved synchrotron infrared microspectroscopy of plant tissue in situ. Cell. Mol. Biol. 44:145-168.

Yu, P. 2004. Application of advanced synchrotron-based Fourier transform infrared microspectroscopy (SR-FTIR) to animal nutrition and feed science: A novel approach. Br. J. Nutr. 92:869-885.

Yu, P., D. A. Christensen, and J. J. McKinnon. 2003a. Comparison of the National Research Concil-2001 model with the Dutch system (DVE/OEB) in the prediction of nutrient supply to dairy cow from forages. J. Dairy Sci. 86:2178-2192.

Yu, P., J. O. Goelema, B. J. Leury, S. Tamminga, and A. R. Egan. 2002. An analysis of the nutritive value of heat processed legume seeds for animal production using the DVE/OEB model: A review. Anim. Feed Sci. Technol. 99:141-176.

Yu, P., J. J. McKinnon, C. R. Christensen, and D. A. Christensen. 2004. Using synchrotron-based FTIR microspectroscopy to reveal chemical features of feather protein secondary structure: Comparison with other feed protein sources. J. Agric. Food Chem. 52:7353-7361.

Yu, P., J. J. McKinnon, H. W. Soita, C. R. Christensen, and D. A. Christensen. 2005. Use of synchrotron-based FTIR microspectroscopy to determine protein secondary structures of raw and heattreated brown and golden flaxseeds: A novel approach. Can. J. Anim. Sci. 85:437-448.

Yu, P., J. Meier, D. A. Christensen, B. Rossnagel, and J. J. McKinnon. 2003b. Using the NRC-2001 model and the DVE/OEB system to evaluate nutritive values of Harrington (malting-type) and Valier (feed-type) barley for ruminants. Anim. Feed Sci. Technol. 107:45-60.

Yu, P., M. Sprague, A. R. Egan, G. H. Castleman, and B. J. Leury. 2001. Comparison of raw and roasted narbon beans (Vicia narbonensis) on performance and meat sensory attributes of lambs fed a roughage-based diet. Anim. Feed Sci. Technol. 92:1-16. 